مقاله مورد شاهدى

مجله دانشگاه علوم :زشكى رفسنجان

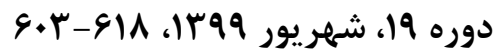

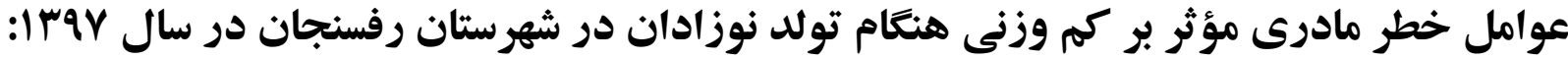

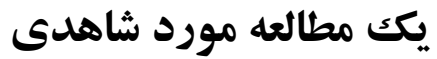

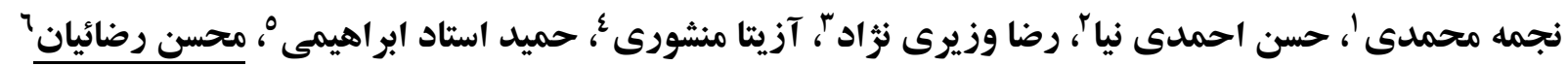

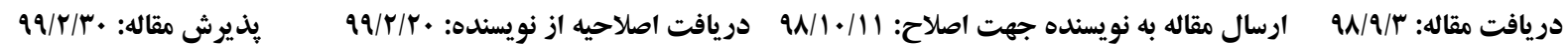
جکكيده

زمينه و هدف: كم وزنى هنكام تولد يكى از مشكلات عمده بهداشت عمومى به شمار مىآيد و با ميزان بالاى مرى در دوره نوزادى ارتباط دارد. اين مطالعه با هدف تعيين عوامل خطر مادرى مؤثر بر كم وزنى هنعام تولد نوزادان در سطح بيمارستانهاى شهرستان رفسنجان طراحى گرديد.

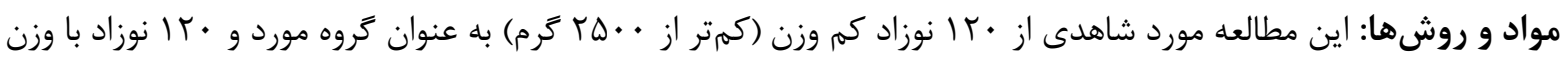

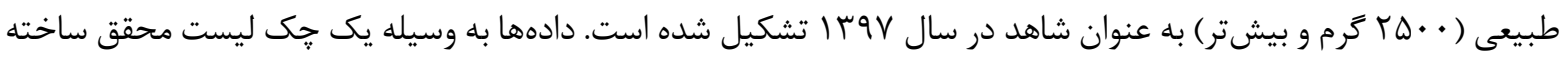
به طور تصادفى از روى يرونده مادران زايمان كرده در بيمارستانهاى شهرستان رفسنجان جمع آورى و دادهها با استفاده از آزمونهاى آمارى مجذور كاى، t مستقل و ركرسيون لجستيك تجزيه و تحليل شدند.

يافتهها: بر اساس نتايج آزمونها تعداد مراقبتهاى باردارى و سن باردارى هنعام زايمان در گروه مورد كمتر از شاهد بود اما

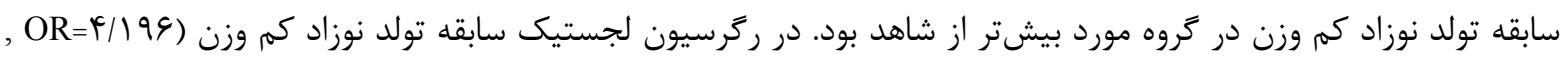

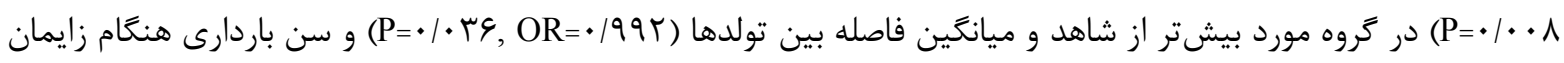
(P< در كروه مورد كمتر از شاهد بود.

نتيجهَيرى: كم بودن تعداد مراقبتهاى باردارى، داشتن سابقه تولد نوزاد كم وزن، زايمان زودرس و فاصله كم بين زايمانها در تولد نوزاد كم وزن نقش دارد. لذا مراقبتهاى باردارى و توجه به مادرانى كه سابقه تولد نوزاد كم وزن و زايمان زودرس دارند و افزايش فاصله بين زايمانها مى تواند باعث كاهش تولد نوزاد كم وزن شود. وازههاى كليدى: كم وزنى، نوزاد، عوامل خطر، رفسنجان

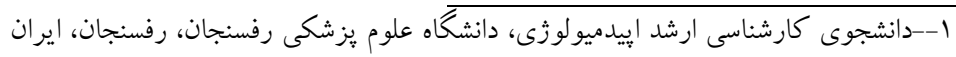

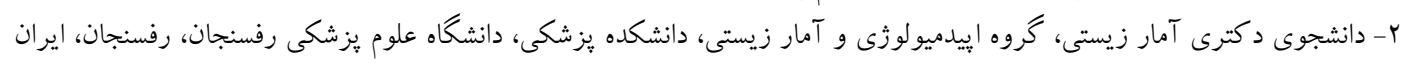

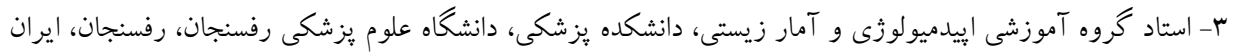

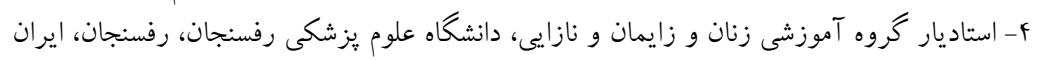

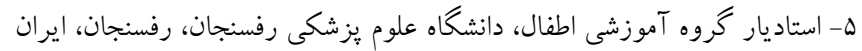

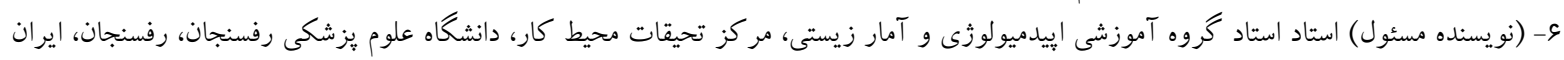

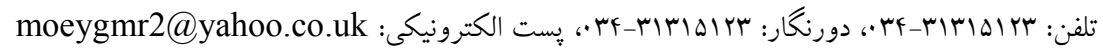


كم وزنى هنگام تولد يكى از گستردهترين مشكلات مقدمه

بهداشت عمومىبه شمار مى آيد [^] و ارتباط تنكاتنكى با ميزان بالاى مرى و ابتلاء دارد [9]. با توجه به افزايش بروز كم وزنى در سالهاى اخير سازمان بهداشت جهانى يكى از اهداف خود را بر دستيابى به كاهش •r درصدى نوزادان با

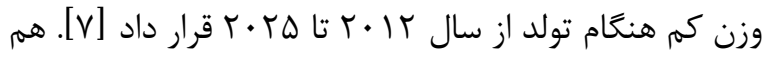
جنين اداره بهداشت آمريكا هدف خود را بر كاهش ه درصدى

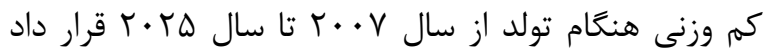

طى بررسىهاى انجام شده، ساليانه به طور تقريبى • 11 ميليون نوزاد در جهان متولد مىشوند كه تقريبا بr ميليون

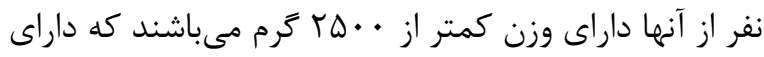
شيوعى برابر با ع| درصد است. اين ميزان در كشورهاى در حال توسعه سا درصد، در آمريكا 9 درصد، در شرق آسيا و اقيانوس آرام ع درصد، در جنوب صحراى آفريقا سا درصد و در جنوب آسيا تا مY درصد تزارش شده است [V، 11]. بر اساس مطالعات انجام شده در ايران، ميزان شيوع كم

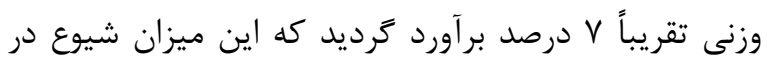
نواحى مختلف ايران متفاوت است. به طورى كه در شرق و غرب ايران تقريبا \ درصد، در جنوب كشور عا درصد، در مركز V درصد و در جنوب شرق تقريباً 9 درصد به دست آمده و كمترين شيوع متعلق به جنوب غرب، شمال و شمال غرب

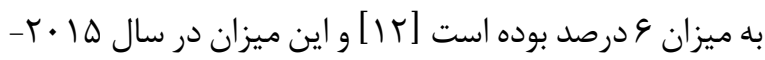

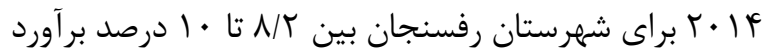
شده است [11]].
تجارب اوليه دوران كودكى پايههاى حياتى را براى تمام دوران زندگى بنا مى كند. نتايج اين تجارب، بهبود سلامتى در سراسر دوران زندگى و افزايش بازده اقتصادى به جامعه از طريق كاهش هزينههاى مراقبتى را به ارمغان مى آورد [؟-1]. هيج شاخصى در زندگى انسان مانند وزن هنكام تولد وجود ندارد كه درباره وقايع كذشته و مسير آينده زندگى صحبت كند. زندگى جنينى و خارج رحمى در امتداد يكديگر مسيرى را مشخص مىسازند كه طى آن، رشد و تكامل كودكان تحت تأثير عوامل زنتيكى، محيطى و اجتماعى رقم مىخورد. حوادث حول تولد كه تحت تأثير عوامل مادرى و جنينى قرار دارند، مىتوانند مشكلات فراوانى را براى نوزاد به وجود بياورند. در اين ميان وزن كم هنغام تولد همواره به عنوان يكى از عوامل تأثير گذار بر مرگ نوزادان و از علل عمده اختلالات تكاملى و عوارض نوزادى مطرح مىباشند [r-r]. طبق تعريف سازمان بهداشت جهانى كم وزنى، به وزن كم تر از .ده گرم در زمان تولد و كم وزنى شديد به وزن كمتر از ها كرم اطلاق مىشود [ه]. اين مقدار مشخص بر اساس مشاهدات إيدميولوزيك مبنى بر اينكه نوزادان با وزن كمتر

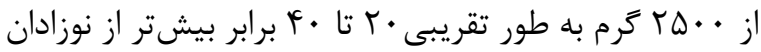
با وزن تولد طبيعى در معرض مرگ قرار دارند، تعيين شده است [ع ،r] و در مقابل كم وزنى، وزن طبيعى هنگام تولد • . . . . . بيش وزنى يا ماكروزومى محسوب مىشود [V].] 


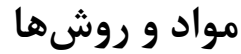

اين مطالعه تحليلى از نوع مورد شاهدى مىباشد. گروه مورد به افرادى از يك جمعيت كفته مىشود كه بيمارى، اختلال سلامت و يا هر حالت ديگر مورد بررسى را دارا باشد و كروه شاهد به افرادى گ كتهه مىشود كه فاقد موارد كفته شده باشد و با كروه مورد مقايسه مىشوند [ ·r] يس از اين كه مجوز انجام اين طرح با كد اخلاق IR.RUMS.REC.1398.033 از معاونت يزوهشى دانشكاه علوم يزشكى رفسنجان اخذ گرديد اطلاعات مورد نياز جمع آورى شد. جامعه آمارى شامل نوزادان متولد شده در سال و I در بيمارستانهاى شهرستان رفسنجان بود. شهرستان رفسنجان يكى از شهرستانهاى استان كرمان واقع در موقعيت جغرافيايى جنوب شرق كشور

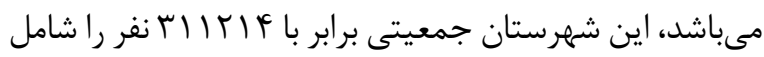
مىشود. اين شهر جزو توليدكنندهاى يسته در جهان مىباشد و پِيشه شغلى بيشتر مردم آن كشاورزى است. اين شهرستان داراى دو بيمارستان مرادى و على ابن ابيطالب (ع) و يك زايشگاه به نام نيك نفس مىباشد كه بيشتر زايمانها در اين زايشكاه انجام مىشود و موارد يرخطر از جمله بيشتر زايمانهاى زودرس به بيمارستان على ابن ابيطالب (ع) ارجاع

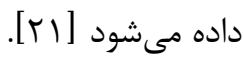

در مطالعه حاضر، با استفاده از مطالعه انجام شده توسط Zarbakhsh Bhari در دوران باردارى مناسبترين حجم نمونه را به دست داد و ميزان مصرف آن در مادران داراى نوزاد با وزن طبيعى و كم وزن به ترتيب برابر با //• و ع / • زارش شد. با استفاده از 9رمول زير، با سطح اطمينان ه9 درصد و توان آمارى .
اگر جه خدمات بهداشت مادر و كودى به طور گسترداى گَترش يافته است، اما زنان در دوران باردارى هنوز با مشكلات بهداشتى زيادى روبه رو هستند كه زندگى آنان را در معرض خطر قرار مىدهد [4 | []]. طبق بررسىهاى انجام شده، عوامل خطر مختلفى وضعيت رشد جنين را تعيين مى كند. از جمله عوامل مادرى مؤثر بر كم وزنى هنعَام تولد مىتوان به عوامل زنتيكى، دردهاى زودرس زايمانى، باردارىهاى متعدد، بيمارىهاى دوران باردارى، سابقه مصرف دارو و دخانيات، سن مادر و اضافه وزن و جاقى در مادر اشاره كرد [ه1]]. مطالعات انجام شده نشان مىدهند كه عوامل زنتيكى، اجتماعى، بيولوزيك و به طوركلى هر عاملى كه بر سلامت مادر مؤثر باشد مىتواند رشد جنين را نيز تحت تأثير قرار دهد [ع1]. ويزگگى هاى آنترويومتريك مادر از قبيل وزن كه بيانكر دريافت كافى انرزى و جثه كه بر اندازه جفت مؤثر است مىتوانند به طور مستقيم بر وزن نوزاد اثرگذار باشند. شيوه زندگى مادر ماند استعمال دخانيات به واسطه نيكوتين و ساير تركيبات مضر مىتواند سلامت جنين را تهديد كند

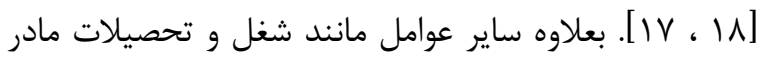
مىتواند سلامت مادر و جنين را تحت تأثير قرار دهند [19]. از آنجايى كه تا به حال هيج مطالعه مورد شاهدى در شهرستان رفسنجان جهت بررسى تأثير عوامل خطر مادرى بر روى كم وزنى هنعَام تولد انجام نشده است و از آنجا كه عوامل اجتماعى، فرهنگى و آداب و رسوم هر منطقه ازجمله عوامل تأثير گذار بر سلامت مادر و جنين است، لذا مطالعه حاضر با هدف تعيين عوامل خطر مادرى مرتبط با تولد نوزادان كم وزن در شهرستان رفسنجان در سال Vوسا طراحى و اجرا شد. 
4.9 عوامل خطر مادرى مؤثر بر كم وزنى هنگام تولد نوزادان در ...

اطلاعات ثبت شده در اين يروندهها شامل وزن و جنس نوزاد، سن مادر، تعداد بارداى، نسبت خويشاوندى، سابقه مصرف هر نوع مواد دخانى، سابقه مصرف دارو در باردارى، سن باردارى هنگًام زايمان، نوع زايمان، سابقه سقط، سابقه مرده زايى و مليت مادر بود. ساير متغيرهاى مورد بررسى از جمله تحصيلات و شغل مادر، تعداد مراقبتهاى دوران باردارى، نمايه توده بدنى در ابتداى باردارى، سابقه تولد نوزاد كم وزن، فاصله تولد نوزاد تا زايمان قبلى، سابقه بيمارى در باردارى و ميزان وزن گيرى مادر در طول باردارى در يروندهها ثبت نشده بود كه از طريق تماس تلفنى و موافقت آكاهانه مادران جمع

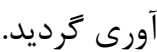

معيارهاى ورود به مطالعه داشتن مليت ايرانى و تولد در بيمارستانهاى على ابن ابيطالب (ع) و نيك نفس شهرستان

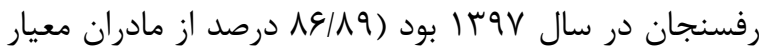
ورود به مطالعه را داشتند).

معيارهاى خروج از مطالعه شامل ناقص يا ناخوانا بودن اطلاعات مربوط به نوزاد و يا در دسترس نبودن مادران و يا مادرانى كه تمايلى به همكارى نداشتند بود.

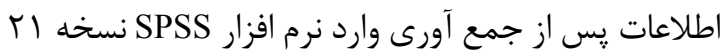
شد. در تجزيه و تحليل دادهها از آمار توصيفى براى ويزگى هاى كلى نمونه مورد بررسى، از آزمون t مستقل براى مقايسه متغيرهاى كمى و آزمون مجذور كاى و دقيق فيشر براى مقايسه متغيرهاى كيفى بين دو گروه مورد و شاهد استفاده شد. سيس تمامىمتغيرها وارد مدل ركرسيون لجستيك شد. سطح معنى دارى در تمام آزمونها برابر با ه • • در نظر ترفته
درصد حجم نمونه در هر گروه • ا نفر و در مجموع ·F نفر محاسبه گَرديد. $\mathrm{n}=\frac{2\left(Z_{1-\frac{\alpha}{2}}+Z_{1-\beta}\right)^{2} \bar{P}(1-\bar{P})}{\left(P_{1}-P_{2}\right)^{2}}$ تعداد يروندههاى مادران زايمان كرده در بيمارستانهاى على ابن ابيطالب (ع) و نيك نفس شهرستان رفسنجان در سال Vq گروه مورد به صورت نمونه گيرى تصادفى ساده از بين يرونده نوزادان كم وزن انتخاب شدند. به اين صورت كه تمامى يرونده

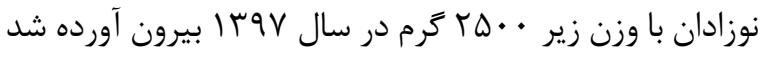
و تعدادى از آنها به صورت تصادفى انتخاب شد. سِس براى هر مورد يك شاهد كه از نظر سن مادر و جنسيت نوزاد با آن همخوانى داشت انتخاب شد. طى بررسى مطالعات مشابه و تأثير متغيرها بر كم وزنى نوزادان، در مطالعه حاضر دو گروه جهت كنترل متغيرهاى مخدوشگر از نظر جنسيت نوزاد و سن مادر همسان سازى شدند به طور مثال براى يك دختر با وزن زير . مr گرم در گروه مورد با يك سن مشخص براى مادر يك دختر با وزن

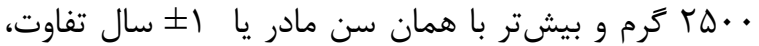
انتخاب گرديد. اطلاعات مورد نياز نوزادان از بيمارستانهاى مربوطه از ارديبهشت تا تير ماه سال ^وسا توسط يزوهشكر جمعآورى شد. اين اطلاعات در جى ليستى محقق ساخته كه به اين منظور توسط يزوهش هيجَّونه نام و نام خانوادگى افراد در جك ليستها ثبت نكَرديد. اين جك ليست از طريق بررسى ساير مطالعات انجام شده با اين موضوع، كَفت و گَ با متخصصين اين حيطه و اهميت اين عوامل خطر در اين شهرستان تدوين گرديد. 
است كه ميانگين تعداد مراقبتهاى دوران باردارى در گروه

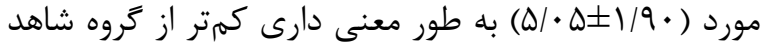

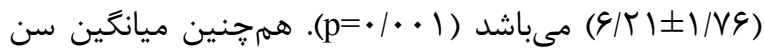

باردارى مادران نوزدان با وزن طبيعى در هنگام زايمان

(r ب/ به طور معنا دارى بيشتر از مادران نوزدان

$$
\text { كم وزن (p= (p=/ }
$$

در اين مطالعه مورد شاهدى كه بين دو گروه مورد (·r

نوزاد) و شاهد (· rا نوزاد) انجام گرديد دو گروه از نظر سن

مادر و جنسيت نوزاد همسان سازى شدند. نتايج حاصل از

تجزيه و تحليل در جداول زير نشان داده شده است. جدول 1

كه در آن متغيرهاى كمى نمايش داده شده است بيانگر اين

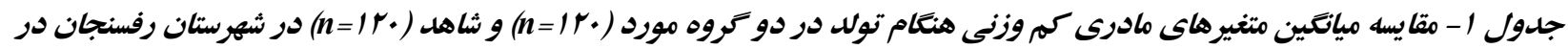

\begin{tabular}{|c|c|c|c|c|c|}
\hline \multirow{2}{*}{ مقدار P " } & \multicolumn{2}{|c|}{ كروه شاهد (• (n=1Y) } & \multicolumn{2}{|c|}{ كروه مورد (·r } & \multirow[b]{2}{*}{ متغير } \\
\hline & أنحر اف معيار & ميانعين & نحر اف معيار & ميانگين & \\
\hline.$/ \varepsilon \vee \varepsilon$ & $T / \cdot r$ & $T / K V$ & T/I & $r / l V$ & كراويد \\
\hline$\cdot / \cdot 1$ & $1 / 17$ & $T / Y)$ & $1 / 9$. & $0 / .0$ & مر اققبت هاى دوران باردارى \\
\hline$. / 90 \leqslant$ & $\varepsilon / \Gamma q$ & $r \varepsilon / N 4$ & $\varepsilon / 71$ & $r \Sigma / \Lambda$. & نمايه توده بدنى در ابتذاى باردارى (kg/m²) \\
\hline$\cdot / \cdot v$ & $r q / \cdot \varepsilon$ & 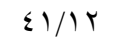 & $\varepsilon \cdot / \times q$ & $\Pi / / \Lambda$ & فاصله تولد نوزادان تاز زايمان \\
\hline.$/ 11 r$ & $0 / 4 V$ & $11 / 1$ & $7 / \cdot \Lambda$ & $9 / 97$ & وزن كيرى در دوران باردارى (kg) \\
\hline.$/ \cdots 1$ & $1 / \pi \varepsilon$ & rN/A. & $r / \Gamma \leqslant$ & พч/q & سن باردارى در هنحام زايمان (هفته) \\
\hline
\end{tabular}

P

در هنگًام زايمان منفى شد و اين مقدار نشان دهنده اين است

كه هر خه سن باردارى در هنگام زايمان بيشتر باشد شانس

تولد نوزاد كم وزن كاهش مىيابد يعنى به ازاى افزايش هر

يك هفته باردارى شانس ابتلاء به كم وزنى وب درصد كاهش

$$
\text { ييدا مى كند. }
$$

همهنين طبق نتايج به دست آمده در جدول r كه متغيرهاى كيفى را نمايش مى دهد، بين كم وزنى هنگًام تولد و سابقه تولد نوزاد كم وزن بين كروه مورد و شاهد ارتباط

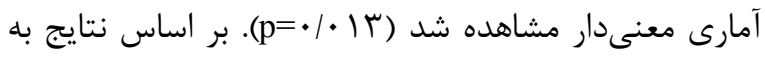
دست آمده در جدول شماره r مربوط به آزمون ركرسيون لجستيك، مقدار بتاى به دست آمده از متغير سن باردارى مادر

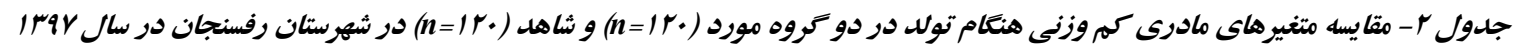

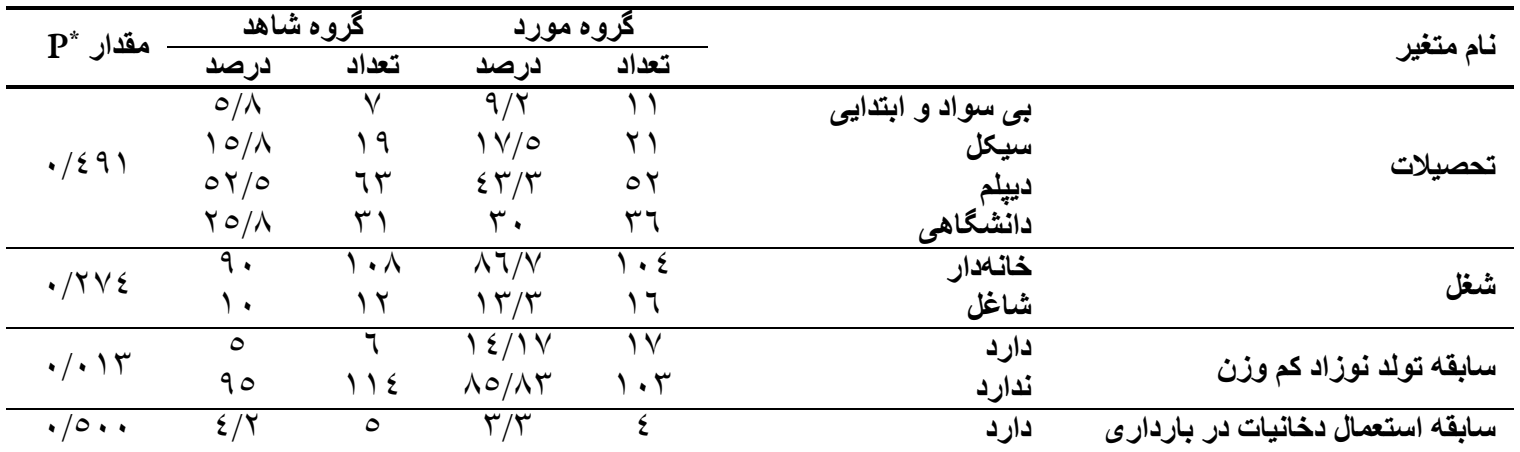

دوره 19، شماره \&، سال 999 19

مجله دانشگاه علوم يزشكى رفسنجان 
^• • عوامل خطر مادرى مؤثر بر كم وزنى هنگام تولد نوزادان در ...

\begin{tabular}{|c|c|c|c|c|c|c|}
\hline & $90 / 1$ & 110 & $97 / \mathrm{V}$ & 117 & ندارد & \multirow{8}{*}{ بيمارى مادر در دوران باردارى } \\
\hline \multirow{7}{*}{$\cdot / \cdot \wedge V^{* *}$} & . & - & $\cdot / \Lambda$ & 1 & بيمارى قلبى & \\
\hline & . & . & $1 / V$ & r & ي بيزاكلاميسي & \\
\hline & $1 \cdot / \Lambda$ & $1 \pi$ & $T / V$ & $\wedge$ & ديابت باردارى و آثكار & \\
\hline & $\Gamma / \Gamma$ & $\varepsilon$ & $\Lambda / \Gamma$ & 1. & برفثارى خون & \\
\hline & $0 / \Lambda$ & $\mathrm{v}$ & r/O & r & كم خونى & \\
\hline & $\cdot / \Lambda$ & 1 & - & - & مشكل كليوى & \\
\hline & $V q / r$ & 90 & $\Lambda$. & 97 & فاقد بيمارى & \\
\hline \multirow{4}{*}{.$/ 70 \mathrm{~V}$} & $11 / \Gamma$ & Tr & $T \Sigma / T$ & rq & ل درجه يك & \multirow{4}{*}{ ازدواج فاميلى } \\
\hline & $\varepsilon / T$ & 0 & 0 & 7 & ل درجه دو & \\
\hline & $1 \cdot / 1$ & $1 \pi$ & $\Lambda / \Gamma$ & 1. & دور & \\
\hline & $74 / \mathrm{V}$ & $\Lambda$. & $T Y / 0$ & vo & نسبتى ندارد & \\
\hline \multirow{2}{*}{.1 .04} & $\Gamma \cdot / \Lambda$ & $T V$ & $\varepsilon / / V$ & 0. & دارد & \multirow{2}{*}{ سابقه مصرف دارو } \\
\hline & $79 / 4$ & Nז & $0 \wedge, \Gamma$ & v. & ندارد & \\
\hline \multirow{4}{*}{.$/ 191$} & $10 / 1$ & 19 & $1 \mathrm{~V} / 0$ & r) & يكبار & \multirow{4}{*}{ سابقه سقط } \\
\hline & $T / V$ & $\Lambda$ & $\Lambda / \Gamma$ & 1 . & دوبار & \\
\hline & - & $\cdot$ & $r / 0$ & $r$ & سله بار & \\
\hline & $V V / 0$ & $q \pi$ & $\checkmark) / V$ & ᄉ & فاقد سقط & \\
\hline \multirow{2}{*}{$\cdot / 419$} & $1 / V$ & $r$ & $1 / V$ & r & يكبار & \multirow{2}{*}{ سابقه مرده زايى } \\
\hline & $91 / \Gamma$ & 111 & $91 / \Gamma$ & 111 & فاقد مرده زايى & \\
\hline \multirow{2}{*}{$\cdot / l \leq V$} & $\leqslant 0$ & $0 \leq$ & $T V / 0$ & $\leqslant 0$ & طبيعى & \multirow{2}{*}{ 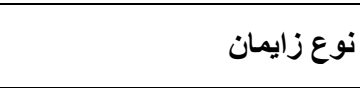 } \\
\hline & 00 & 77 & $T Y / 0$ & vo & سزارين & \\
\hline
\end{tabular}

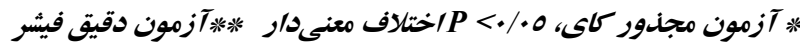

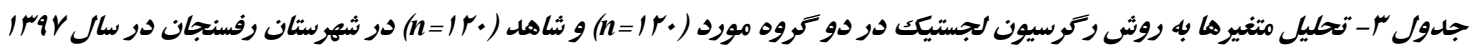

\begin{tabular}{|c|c|c|c|c|}
\hline Pقدار P P P & CI for OR & OR & $\begin{array}{l}\text { ضريب ركرسيونى (B) } \\
\text { (B) }\end{array}$ & متغير ها \\
\hline$\cdot 1 \cdot \cdots$ & $\left(\cdot / 01 V_{6} \cdot / / 19\right)$ & .191. &.$- / 490$ & سايمان (هفته) مادران در هنحام \\
\hline$\cdot \cdots \wedge$ & $(1 / F Y \Delta, I Y / / \Lambda \Lambda)$ & $4 / 199$ & I/FTH & سابقه تولد نوزاد كم وزن در مادران \\
\hline $.1 \cdot 49$ & $(\cdot / 9106 \cdot \cdot / 999)$ &.$/ 994$ & $-\cdot / \cdot \Lambda$ & فادرانه بين تولد تاز زايمان قبلى \\
\hline
\end{tabular}

متغيرها با روش Backward انتخاب و وارد مدل ركرسيونى

شدند به اين صورت كه ابتدا تمام متغيرها وارد مدل شدند

سيس طى جندين مرحله متغيرهايى كه معنىدار نبودند از

مدل خارج شدند. اثر ديخر متغيرهاى مورد بررسى در اين مطالعه از جمله سطح تحصيلات، شغل و نمايه توده بدنى مادر در ابتداى باردارى، سابقه مصرف دخانيات در باردارى، سابقه مصرف دارو در باردارى، سابقه بيمارىهاى مادر در باردارى
همرجنين نشان داده شد كه شانس تولد نوزاد كم وزن در مادرانى كه سابقه تولد نوزاد كم وزن داشتند 9 F/19 برابر مادرانى بود كه سابقه تولد نوزاد كم وزن نداشتند. در اين مدل نيز نشان داده شد كه هر جه فاصله بين زايمانها بيشتر شود شانس تولد نوزاد كم وزن كاهش يِيدا مى كند و به ازاى هر ماه افزايش فاصله بين زايمانها شانس تولد نوزاد كم وزن ^ • • • كاهش مىيابد. 
جيرفت بود در اين بررسى نشان داده شد كه به ازاى هر بار مراقبت دوران باردارى شانس تولد نوزاد كم وزن $1 /$ برابر كاهش مىيابد [rr]]. همرجنين طبق نتايج مطالعه انجام شده توسط Dulal و همكاران در هندوستان، مادرانى كه در دوران باردارى كمتر از ץ بار مراقبت شدهاند 9 • † برابر ديكر مادران داراى شانس تولد نوزاد كم وزن بودند [TF]. همجنين مطالعه حاضر، رابطه معنى دارى بين كم وزنى هنگام تولد و سابقه تولد نوزاد كم وزن در گروه مورد و شاهد مشاهده شد به طورى كه سابقه تولد نوزاد كم وزن در مادران كروه مورد بيشتر بود كه اين يافتهها با نتايج مطالعه انجام شده توسط Domple و همكاران در هندوستان همخوانى دارد كه نشان داد هT درصد از مادران نوزادان كم وزن، سابقه تولد نوزاد كم وزن داشتند [ro]]. همرجنين نتايج يزوهش Sutan و همكاران در مالزى نتايج مطالعه ما را تأييد مى كنند و 19/4 درصد از مادران گروه مورد داراى سابقه تولد نوزاد كم وزن بودند [عץ] و آزمون ركرسيون لجستيك اين نتايج را تأييد كرد به طورى كه شانس تولد نوزاد كم وزن در مادرانى كه سابقه تولد نوزاد كم وزن داشتند 9 أ برابر مادرانى بود كه سابقه تولد نوزاد كم وزن نداشتند. يافتهها نشان داد كه بين كم وزنى زمان تولد و سن باردارى مادر در هنگَام زايمان بين گروه مورد و شاهد ارتباط معنى دارى وجود دارد و ميانگين سن باردارى مادران هنَام زايمان در گروه مورد كمتر از گروه شاهد بود، در مدل ركرسيون لجستيك نيز اين نتايج معنىدار شد و نشان داده
(فشار خون بالا، ديابت، كم خونى و بيمارى كليوى)، ميزان وزن گيرى در دوران باردارى، تعداد باردارى، سابقه سقط و مرده زايى، نوع زايمان و ازدواج فاميلى مادر در وزن هنگام تولد معنى دار نبود. همرجنين اثرات متقابل (Interaction) بين متغيرهايى كه در مدل باقى ماندند نيز مورد بررسى قرار كرفتند كه هيجكدام معنى دارى نشدند (جداول ( و r). همرجنين جهت يررسى نيكويى برازش مدل ركرسيون لجستيك از آزمون Hosmer-Lemeshow استفاده شد كه معنى مناسب مدل ركرسيون لجستيك به اين دادها مىباشد. هم جنين شاخص سطح زير منحنى راى (Area under the ROC

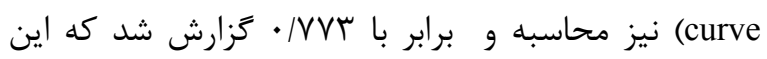
شاخص نيز نشان دهنده برازش مناسب مدل به دادههاى موجود مىباشد.

\section{بحث}

يافتههاى مطالعه ما نشان دهنده آن است كه ميانگين تعداد مراقبتهاى دوران باردارى در گروه مورد كمتر از گروه شاهد مىباشد و بين كم وزنى هنَام تولد و مراقبتهاى دوران باردارى در گروه مورد و شاهد ارتباط معنى دارى وجود دارد. يكى از مهمترين دلايل انجام مراقبتهاى دوران باردارى توسط سيستمهاى بهداشتى، يايش منظم وزن و به علاوه آكاهى سريع از عوارض باردارى از قبيل ديابت، فشارخون بالا، مسموميت باردارى و علائم خطر ديگر است. اين نتايج همسو با بررسىهاى انجام شده توسط Rajizadeh و همكاران در 
• اع عوامل خطر مادرى مؤثر بر كم وزنى هنگام تولد نوزادان در ...

( )

[rq]

طبق يافتهها ميانگين و انحر اف معيار تعداد باردارى مادران در زروه مورد برابر با F r T/YVII/ بود كه اختلاف معنىدارى بين دو گروه مشاهده نكرديد و اين نتايج همسو با مطالعه انجام شده توسط و همكاران در بيرجند با ميانگين ع/ • Salehiniya

كروه مورد و 9 / • در اين بررسى ميانگين و انحراف معيار نمايه توده بدنى در

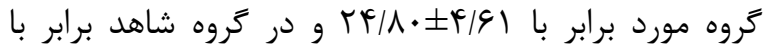
q q/Y معنىدارى نبود و اين نتايج با مطالعه انجام شده توسط و همكاران در تهران با ميانگين Fahmoodi

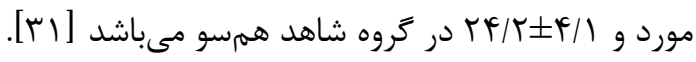
در اين يزوهش ميانخين فاصله تولد نوزاد با زايمان قبلى

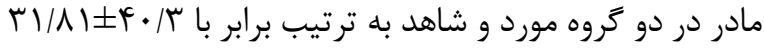
ماه (r/r/r سال) به دست آمد. كه از نظر آمارى داراى اختلاف معنى دارى نبود. اين نتايج با مطالعه انجام شده توسط Eghbalian در

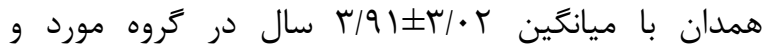

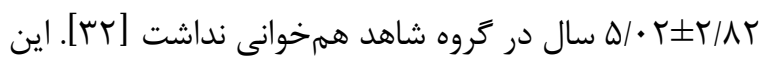
يافته شايد به اين علت باشد كه در مطالعه ما بيشتر مادران در هر دو گروه با توجه به آموزشهاى برَزار شده در مراكز
شد كه هر جه سن باردارى در هنخام زايمان بيشتر باشد شانس تولد نوزاد كم وزن كاهش مىيابد و به ازاى افزايش هر يك هفته باردارى شانس ابتلاء به كم وزنى 9 ب درصد كاهش ريدا مى كند. اين نتايج هم راستا با نتايج مطالعه انجام شده توسط Pawar و همكارش در هندوستان بود [YV] و همرجنين اين نتايج همسو با يافتهاى مطالعه انجام شده در كشور مالزى بود و نشان داده شد مادرانى كه كمتر از VIV هفته زايمان كرده بودند VN/Td درصد شانس تولد نوزاد كم وزن در آنها بيشتر مىباشد [rع]. طبق يافتهها سطح تحصيلات بين دو گروه مورد و شاهد داراى اختلاف معنىدارى نبود و بيشترين فراوانى مربوط به تحصيلات دييلم ( //r/א درصد در گروه مورد و در گروه شاهد) بود. اين يافته شايد به اين دليل باشد كه بيش تر مادران در هر دو گروه از تحصيلات مناسبى برخوردار بودند كه اين يافته با نتايج مطالعه انجام شده در Haiti همخوانى داشت، در آن مطالعه همانند يزوهش ما بيشترين فراوانى مربوط به تحصيلات دييلم (\&ه درصد در گروه مورد و هله درصد در گروه شاهد) بود و ارتباط معنى دارى بين گروه مورد

$$
\text { و شاهد مشاهده نكرديد [r/]. }
$$

در اين يزوهش نيز رابطه معنىدارى بين شغل و كم وزنى هنگام تولد بين دو گروه مشاهده نكرديد و بيشتر مادران در هر دو گروه خانهدار (\&/V درصد در گروه مورد و • در گروه شاهد) بودند و تعداد كمى از آنها شاغل بودند كه اين نتيجه همسو با يافتههاى حاصل از مطالعه انجام شده در قطر 
نتايج همسو با مطالعه انجام شده توسط Mirzarahimi و همكاران بود كه نشان داده شد T/F درصد از مادران گروه مورد و بr درصد از مادران كروه شاهد داراى ازدواج فاميلى بودند [بس].

در اين بررسى ميانگين وزن كيرى مادران در دوران باردارى در گروه مورد 9/9 و در گروه شاهد برابر با س//1/ به دست

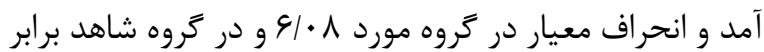
با ه/TV بود و اين مقدار از نظر آمارى داراى اختلاف معنى دارى نبود. در مطالعه Bendhari و همكاران ميانگين وزن گيرى مادران در دوران باردارى در گروه مورد و شاهد به

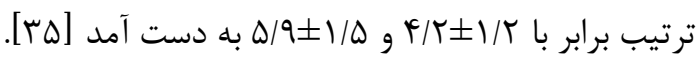
همرجنين در بررسى حاضر اختلاف آمارى معنىدارى بين سابقه مصرف دارو در باردارى و كم وزنى بين دو گروه مشاهده نكَرديد كه با توجه به اينكه مطالعات انجام شده در زمينه تأثير داروهاى مصرفى در دوران بادارى مادر بر كم وزنى نوزاد محدود مىباشد اين متغير مىتواند يك متغير جديد در زمينه كم وزنى نوزادان در هنگام تولد باشد.

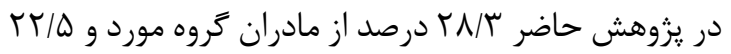
درصد از مادران گَروه شاهد داراى سابقه سقط بودند كه از نظر آمارى داراى اختلاف معنىدارى نبود. تنها / ا درصد از مادران در هر دو گروه مورد و شاهد داراى سابقه مرده زايى بودند. در مطالعه انجام شده در ايالت Karnataka در كشور هند سابقه سقط و مرده زايى در گروه مورد و شاهد به ترتيب برابر با V/N و N/V درصد بود كه از نظر آمارى معنى دار نبود
بهداشتى و درمانى فاصله معمول بين باردارىها را رعايت كرده

بر اساس يافتهها سابقه مصرف دخانيات در دوران باردارى داراى ارتباط معنىدارى بين دو گروه نبود و تعداد كمى از مادران در هر دو گروه مورد و شاهد سابقه مصرف دخانيات در دوران باردارى بودند، در رابطه با اين متغير اين امكان وجود دارد كه برخى از مادران سابقه مصرف دخانيات را ذكر نكرده باشند. اين يافته همسو با نتايج يزوهش انجام شده توسط Mirzarahimi درصد) از گروه مورد سابقه اعتياد داشتند و ارتباط معنىدارى مشاهده نكرديد [سب]. در اين بررسى همجنين رابطه معنى دارى بين بيمارىهاى دوران باردارى و كم وزنى بين دو گروه مشاهده نكرديد و تعداد

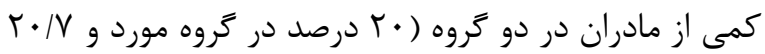
درصد در گروه شاهد) داراى سابقه بيمارى در دوران باردارى بودند. اين نتايج همسو با مطالعه انجام شده در Nepal بود، آن يزوهش نيز نشان داد كه تعداد كمى از مادران در هر دو گروه سابقه بيمارى در دوران باردارى داشتند به اين صورت كه 9/V درصد از مادران ₹روه مورد و // ه/ درصد از زروه شاهد داراى سابقه بيمارى در دوران باردارى بودند كه اين اختلاف

$$
\text { از نظر آمارى معنى دار نبود [MF]. }
$$

در اين مطالعه ف/W/ درصد از مادران گروه مورد و درصد از مادران گروه شاهد داراى ازدواج فاميلى درجه ل، و دور بودند اما اين اختلاف از نظر آمارى معنىدار نبود. اين 
ז اوعوامل خطر مادرى مؤثر بر كم وزنى هنگام تولد نوزادان در ...

سن باردارى يايين در هنكام زايمان و كم بودن فاصله بين زايمانها مىتواند نقش مهمى در تولد نوزاد كم وزن داشته باشد. بنابراين افزايش يوشش مراقبتهاى دوران باردارى، افزايش فاصله بين زايمانها و توجه ويزه به مادرانى كه سابقه تولد نوزاد كم وزن دارند و كاهش عوامل خطر زايمان زودرس مىتواند در كاهش تولد نوزاد كم وزن نقش مهمى ايفاء كند.

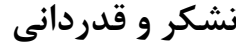

اين مقاله حاصل بايان نامه دانشجويى خانم نجمه محمدى براى اخذ درجه كارشناسى ارشد در رشته إِيدميولوزى از دانشگاه علوم يزشكى رفسنجان است. بدين وسيله لازم است از معاونت محترم يزوهشى دانشگاه علوم يزشكى رفسنجان به خاطر حمايتهاى مالى و كليه كارمندان واحد مدارك يزشكى زايشكاه نيك نفس و بيمارستان على ابن ابيطالب (ع) شهرستان رفسنجان و مادران عزيزى كه در انجام اين تحقيق ما را يارى نمودند كمال تشكر و

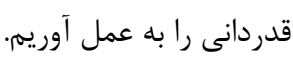

[عَ]. در اين بررسى بيشتر مادران در هر دو كروه به روش سزارين زايمان كرده (DN/VQ درصد) بودند و در گروه مورد زايمان به اين روش بيشتر بود اما اين اختلاف از نظر آمارى معنىدار نبود. بر اساس مطالعه انجام شده در استان مركزى FA/F درصد از مادران به روش سزارين زايمان كرده بودند كه آن نتايج مانند نتايج مطالعه حاضر داراى اختلاف آمارى معنى دارى نبود [rV]. بيشنهاد مىشود كه در بررسىهاى بعدى تمامىمادران از جمله مادرانى كه در منزل زايمان كرده اند مورد يزوهش قرار گيرند و ديگر عوامل خطر احتمالى از جمله تغذيه مادر و وضعيت قبل از باردارى مادر نيز بررسى شود. همرجنين در مورد اهميت اين موضوع دورههاى آموزشى براى كار كنان برنامه برَزار شود و در مراكز بهداشتى و درمانى ارزشيابى جامع از اين مشكل به عمل آيد.

\section{نتيجهلَيرى}

يافتههاى اين بررسى نشان داد كه كم بودن تعداد مراقبتهاى دوران باردارى، داشتن سابقه تولد نوزاد كم وزن،

\section{References}

[1] Health WCoSDo, Organization WH. Closing the gap in a generation: health equity through action on the social determinants of health: final report of the Commission on Social
Determinants of Health: World Health Organization; 2008. 
[2] Ettinger AS. Children's Health, The Nation's

Wealth: Assessing and Improving Child Health. EHPJ 2004; 112 (14): 844.

[3] Sharifzadeh GH, Ayatallahi A, Rajaeefard A, Namakin K. Epidemiologic study of infant mortality and its risk factors in Birjand health houses in rural areas are covered. JBUMS 2013; 10(3): 9-15. [Farsi]

[4] Solimani F. Developmental Outcome of Low Birth Weight Premature Infants. IJP 2007; 17(1): 125-35. [Farsi]

[5] Resolution WHA65.6. Comprehensive implementation plan on maternal, infant and young child nutrition. In Sixty-fifth World Health Assembly Geneva. Resolutions and decisions, annexes. Geneva: WHO 2012; 1213.
[6] Low Birth Weight Country, Regional and Global Estimates. The United Nations Children's Fund and WHO 2004; 17.

[7] World Health Organization. Global Nutrition Targets 2025: Low Birth Weight Policy brief. WHO 2014; 1-8.

[8] Suryakantha AH. Maternal and Child Health Services. In Community Medicine with Recent Advances. 4th edn. New Delhi: Jaypee brothers Medical Publishers; 2017; 614.

[9]Behrman R, Klieghman R, Jenson H. Nelson's Textbook of Pediatrics 17th ed. Saunders. Philadelphia p 2004; 1479: 547-58.

[10] New York State Department of Health: Table 11: Low Birth weight Live Births (2500 grams) by Mother's Age and Resident County New York State 2009. 
[11] United Nations Children's Fund.

Undernourishment in the womb can lead to diminished potential and predispose infants to early death 2014 .

[12] Nazari F, Vaisi Z, Sayehmiri K, Vaisani Y, Esteki T. Prevalence and trends of low birth weight in Iran: a systematic review and metaanalysis study. JSBUNM 2013; 22(79): 16-23.

[Farsi]

[13] Momeni M, Danaei M, Kermani AJ, Bakhshandeh M, Foroodnia S, Mahmoudabadi Z, et al. Prevalence and risk factors of low birth weight in the Southeast of Iran. IJPM 2017; 8:

12. [Farsi]

[14] Gharaibeh M, Al-Maitah R, Al Jada N. Lifestyle practices of Jordanian pregnant women. ICN 2005; 52: 92-100.
[15] Mayer C, Joseph KS. Fetal growth: a review of terms, concepts and issues relevant to obstetrics. UOG 2013; (41): 136-45.

[16] Slemming W, Bello B, Saloojee H, Richter L. Maternal risk exposure during pregnancy and infant birth weight. EHD 2016; (99): 31-6.

[17] Asefa F, Nemomsa D. Gestational weight gain and its associated factors in Harari Regional State: Institution based cross-sectional study, Eastern Ethiopia. RH 2016; (13): 101.

[18 ]Robinson O, Martinez D, Aurrekoetxea JJ, Estarlich M, Somoano AF, Iniguez C, et al. The association between passive and active tobacco smoke exposure and child weight status among Spanish children. JO 2016; (24): 1767-77.

[19] Momeni M, Esfandyarpour R, Danaei M. The neglected sociobehavioral risk factors of low birth weight. SDH 2016; (1): 97-103. 
[20] Nasseri K. A Comprehensive Dictionary of Epidemiology. 1th ed. GAP, 2010.

[21] IRAN STATISTICAL YEARBOOK. Census of the Islamic Republic of Iran, 2016; (1395)" (Excel).

[22] Zarbakhsh Bhari M R, Hoseinian S, Afrooz Gh

A, Hooman H A. Prevalence of Low Birth Weight and Comparison of Many Biological Characteristics of Low Birth Weight. JGUMS 2011; (81): 37-44. [Farsi]

[23] Rajizadeh A, Samimi Sh, Momeni M. Investigation of the factors related to low birth weight in the south of Iran: a case-control Study. SJKUMS 2018; (94). [Farsi]

[24] Dalal A, Chauhan S, Bala DV. Epidemiological determinants of low birth weight in Ahmedabad city: A facility based case-control study. IJMSPH 2014; (3): 430-2.
[25] Domple VK, Doibale MK, Nair A, Rajput PS. Assessment of Maternal risk factors associated with Low Birth Weight neonates at a tertiary hospital, Nanded, Maharashtra. NMJ 2016; 57(1): 37-43.

[26] Sutan R, Mohtar M, Mahat AN, and Tamil AM. Determinant of Low Birth Weight Infants. A Matched Case Control Study. OJPM 2014; (4): 91-9.

[27] Pawar A, Kumar D. Maternal factors associated with low birth weight: a case control study in rural Kerala. IJCMPH 2017; (4): 3793-5.

[28] Rashid A, Park T, Macneal K, Iannotti L, Ross W. Maternal diet and morbidity factors associated with low birth weight in Haiti: a case-control study, Health Equity 2:1, 2017; $139-44$.

[29] Abdulbari Bener, Najah Mohammed Saleh, Khalil Mohd Khalil Salameh, Basma Basha, 
عاع عوامل خطر مادرى مؤثر بر كم وزنى هنغام تولد نوزادان در ...

Sharen Joseph, Rama Al Buz. Sociodemographic and consanguinity risk factors associated with low birth weight. JPMA 2013; 63(5).

[30] Salehiniya H, Mohamadkhani-Shahri L, SabetBirjandi S. The relationship of Maternal Serum Magnesium Levels and the Incidence of Low Birth Weight Infants: A Case-Control Study. JIMS 2014; 32(282): 507-13. [Farsi]

[31] Mahmoodi Z, Karimlou M, Sajjadi H, Dejman M, Vameghi M, Dolatian M. A Communicative Model of Mothers' Lifestyles during Pregnancy with Low Birth Weight Based on Social Determinants of Health: A Path Analysis. OMJ 2017; 32 (4): 306-14. [Farsi]

[32] Eghbalian F. Low birth weight causes survey in neonates. IJP 2007; 17(1): 27-33. [Farsi]
[33] Mirzarahimi M, Saadati H, Berack M, Abasgholizadeh N, Azamie A, Enteshari T. Incidence and Risk factors of Low Birth Weight infants. JAUMS 2009; 9(1): 69-79. [Farsi]

[34] A Sharma SR, Giri S, Timalsina U, Bhandari SS, Basyal B, Wagle K, et al. Low Birth Weight at Term and Its Determinants in a Tertiary Hospital of Nepal: A Case-Control Study. PLoS ONE 2015; 10(4).

[35] Bendhari ML, Haralkar SJ. Study of maternal risk factors for low birth weight neonates: a case- control study. IJMSPH 2015; (4): 98790.

[36] Ganesh Kumar S, Harsha Kumar H N, Jayaram S, Kotian M S. Determinants of Low Birth Weight: A Case Control Study in a District Hospital in Karnataka. IJP 2010 (17). 
[37] Ranjbaran M, Jafary-Manesh H, Sajjadi-

Hazaneh L, Eisaabadi S, Talkhabi SH, Khoshniyat AS, et al. Prevalence of Low Birth
Weight and Some Associated Factors in Markazi Province. WJMS 2015. 12(3): 252-8. [Farsi]. 
11 اوعوامل خطر مادرى مؤثر بر كم وزنى هنگام تولد نوزادان در ...

\title{
Maternal Risk Factors Affecting Low Birth Weight in Rafsanjan Township in 2018: A Case Control Study
}

\author{
N. Mohamadi ${ }^{1}$, H. Ahmadinia ${ }^{2}$, R. Vaziri Nejad ${ }^{3}$, A. Manshoori ${ }^{4}$, H. Ostad Ebrahimi ${ }^{5}, \underline{\text { M. Rezaeian }}^{6}$ \\ Received: 24/11/2019 Sent for Revision: 01/01/2020 Received Revised Manuscript: 09/05/2020 Accepted: 19/05/2020
}

Background and Objectives: Low birth weight is one of the most widespread public health problems associated with high infant mortality. This study aimed to identify maternal risk factors affecting low birth weight neonates in Rafsanjan hospitals.

Materials and Methods: This case-control study consisted of 120 low birth weight infants (less than 2500 grams) as the case group and 120 normal weight infants (2500 grams and more) as controls in 2018. The data were collected by a randomized checklist from the records of the delivery mothers in the hospitals of Rafsanjan and were analyzed using Chi-square, independent t-test and logistic regression.

Results: According to the results of the tests, the number of prenatal care and gestational age at birth was lower in the case group than in the control group, but the history of low birth weight was higher in the case group. Logistic regression for the history of low birth weight $(\mathrm{OR}=4.196, \mathrm{p}=0.008)$ in the case group was more than the control and mean birth interval $(\mathrm{OR}=0.992, \mathrm{p}=0.036)$ and gestational age at birth delivery $(\mathrm{p}<0.001, \mathrm{OR}=0.61)$ was lower in the case group than in the control group.

Conclusion: Findings showed that low number of prenatal care, having low birth weight, preterm delivery, and low birth interval have a role in low birth weight. Therefore, increasing pregnancy care coverage and paying attention to mothers who have low birth weight and preterm birth and increasing the interval between births can decrease low birth weight infants.

Key words: Low birth weight, Infant, Risk factors, Rafsanjan

Funding: This research was funded by Rafsanjan University of Medical Sciences.

Conflict of Interest: None declared.

Ethical approval: The Ethics Committee of Rafsanjan University of Medical Sciences approved the study (IR.RUMS.REC.1398.033).

How to cite this article: Mohamadi N, Ahmadinia H, Vaziri Nejad R, Manshoori A, Ostad Ebrahimi H, Rezaeian M. Maternal Risk Factors Affecting Low Birth Weight in Rafsanjan Township in 2018: A Case Control Study. J Rafsanjan Univ Med Sci 2020; 19 (6): 603-18. [Farsi]

1- MSc Student of Epidemiology, Rafsanjan University of Medical Sciences, Rafsanjan, Iran, ORCID: 0000000185060376 2- PhD Student of Biostatistics, Dept. of Social Epidemiology and Biostatistics, Medical School, Rafsanjan University of Medical Sciences, Rafsanjan, Iran, ORCID: 0000000270101726

3-Prof., Dept. of Social Epidemiology and Biostatistics, Medical School, Rafsanjan University of Medical Sciences, Rafsanjan, Iran, ORCID: 0000000219677631

4 Assistant Prof., Dept. of Gynecology, Rafsanjan University of Medical Scienses, Rafsanjan, Iran, ORCID: 0000000314786377

5-Assistant Prof., Dept. of Pediatrician, Rafsanjan University of Medical Scienses, Rafsanjan, Iran, ORCID: 0000000250530670

6- Prof., Dept. of Social Epidemiology and Biostatistics, Ocupational Environmental Research Center, Medical School, Rafsanjan University of Medical Sciences, Rafsanjan, Iran, ORCID: 0000000330700166

(Corresponding Author) Tel: (034) 31315123, Fax: (034) 31315123, E-mail: moeygmr2@yaho.co.uk

دوره 19، شماره \&، سال 99س1

مجله دانشگاه علوم يزشكى رفسنجان 